\title{
From the Failure of African Socialism, How to Set a New Trend for a New Generation?
}

\author{
Coulibaly Yacouba ${ }^{1}$, Belko Wologueme ${ }^{2}$ \\ ${ }^{1}$ Institute of Marxism School, Department of Philosophy, Central China Normal University, Wuhan, China \\ ${ }^{2}$ Department of Philosophy in FSHSE of Bamako, Bamako, Mali \\ Email: bayacoulib@yahoo.fr, bayacoulib@mail.com, belko_wologueme@yahoo.fr
}

How to cite this paper: Yacouba, C. and Wologueme, B. (2018) From the Failure of African Socialism, How to Set a New Trend for a New Generation? Open Journal of Social Sciences, 6, 27-36. https://doi.org/10.4236/jss.2018.62003

Received: December 16, 2017

Accepted: January 30, 2018

Published: February 2, 2018

Copyright (c) 2018 by authors and Scientific Research Publishing Inc. This work is licensed under the Creative Commons Attribution International License (CC BY 4.0).

http://creativecommons.org/licenses/by/4.0/

(c) (i) Open Access

\begin{abstract}
From 1960, most of the African nations got their political independence. Many countries started to establish national and regional vision about the future. Then some political scientist, state men and scholars came out with a new philosophy called socialism. The concept of socialism was at the same time philosophical and ideological conviction made to promote national and regional unity in Africa. Unfortunately, the concept was misunderstood by most of the leaders to some extent, but also, the lack of good will led some others to mislead their own people by fighting against the idea of socialism. The fact that many Africans were not educated, contributed to the growth and expansion of socialism with effectiveness. For all these reasons, the application of socialism was difficult, even impossible. In this article, we are trying to explain the main reason of the failure of this political and philosophical thought and set a new trend for the new generation.
\end{abstract}

\section{Keywords}

Failure, African Socialism, Trend, Generation

\section{Introduction}

Socialist ideas and practices have been in Africa before the colonialization in nineteenth century. African socialism as ideological thought had strong value in African identity. The similarity among African people is more represented in socialism than anything else. The way most of the African societies are structured, proved that the idea of socialism was already in Africa. The only fact is that Socialism was known in Africa as culture than philosophy. The new concept was a revolutionary idea, and conviction with the purpose to demolish everything that stood against African values. It was a new call into consciousness. 
The concept of socialism was also conceived by African scholars as a platform of ideological and political thoughts and writings. It was conceived in order to encourage one another and promote the hope that the restoration of African people was possible. This political concept was created and developed by African leaders for African Countries and for a common goal. It was unfortunate that there was a contrast between the meaning of the concept and the real intention of some leaders. Very soon socialism became just a simple theory between lips. Because conceptually, African socialism was so strong and meaningful. But through the attitude of some leaders, you could notice the gap between what socialism means and what they are doing. The simple example is the fact that some leaders were involved in corruption which was against the principles of socialism. That is why the authors think that for some leaders, it was just concept and nor conviction.

The other problem with African socialism was the inability of citizens to understand the concept. For example, When Nyerere wrote about essays on socialism, many active party workers and also many teachers in Tanzania and civil servants remained unclear about the most important principles of socialism. In such case, how can somebody expect the other citizens to understand? [1] In the same book, we can read in introduction: "socialism, like democracy, is an attitude of mind. In a socialist society it is the socialist attitude of mind, and not the rigid adherence to a standard political pattern, which is needed to ensure that the people care for each other's welfare." [1] This inability of citizens to understand socialism can be explained by the high intellectual level of those who conceived the concept compared to the numberless uneducated citizens. When the intellectual like Nyerere and others conceived the concept, they forgot that a great number of people would not understand.

One truth remains about socialism: it is the source of restoration of Africa. Even though the first trial failed, socialism is still the main door needed by African people to step into the true independence. The neo-socialism should be the political battle for African leaders to move forward. The new generation should use the lessons from the failure of socialism to empower the new-socialism. To do so, we have to build and develop strategies of information from top to down.

\section{The Genesis of African Socialism}

We can define African socialism as an attempt to recapture and modernize the communal way of life practiced by the traditional African before the contact with the world and values of the white man. Nkrumah defined socialism in a special way when he wrote: "Socialism is a form of social organization which, guided by the principles underlying communism, adopts procedures and measures made necessary by demographic and technological developments" [2]. In this perspective the socialism has to fit with the reality of the society. Tom Mboya, one of the Kenyans political figure conceived African socialism as the best way to restore national values. He was truly and genuinely attached to tradi- 
tional values. The major purpose of African socialism was more about the creation of social values that fit the ideological mind state of African people. The values such as communalism, hospitality, generosity are not new in Africa. They are part of African identity. They are the essence of African society. Looking at African socialism as a philosophy and an ideological conviction, Nkrumah was trying to make a room for each citizen in the concept. Even though the leaders were more focused on the cultural aspect more than a political aspect in most of their discourse; in the practice it was a kind of political system. The fact that many people were not educated, African socialism was the affair of those who were involved in politics. The battle was more political position than a cultural movement. From the beginning we could see the conflict between the theory and the practice. Nyerere has given one of the wonderful definitions of African socialism. According to him: "African socialism is essentially an attitude of the mind which involves a change in personal attitude and a reconciliation of individuals" [1]; this perspective was actually the real need. Changing begins with setting a new state of mind. But to be able to change the mind of somebody, that person has to be exposed to ideological influences and good examples. Unfortunately, African intellectuals failed to developed unity among themselves. As they were divided into political tendency, the citizens also were divided. That was the main reason of the failure of African socialism. It was like promoting unity and division at the same time. The first work had to be done among scholars and intellectuals first and citizens later.

The term "socialism" was a powerful concept which was rich of meaning. It was a complex concept with multidisciplinary targets. It was a complex of social purposes regarding economic policies, organizational patterns, state structure, and ideologies which would led Africa in the achievement of its holistic success. The main idea was to grant African society the socialist vision which will reconcile the humanism of traditional African life with the modern intellectual community [2]. We can say in a short way that the main purpose was to empower Africa in diverse dimension. As many African countries gained independence during the 1960s, some of these fresh governments rejected the ideas of capitalism in favor of a more afro-conception of economic model. African socialists were nationalist-politicians who believed the restoration or restructuration of precolonial community's traditions of social mutualism, social egalitarianism, and a consensus system of political order. According to most of the African socialists, socialism was the best way to bring Africa into the roots of its ancestors with adjustment according to modern thought. Julius Nyerere of Tanzania, Modibo Keita of Mali, Léopold Senghor of Senegal, Kwame Nkrumah of Ghana and Sékou Touré of Guinea, were the main architects of African Socialism.

\section{Socialism as Afro Marxism}

The traditional African society was founded on principles of egalitarianism and communalism. The concept socialism in Africa introduced a new social, ideo- 
logical, philosophical and political thought in which modern perception is reconciled with the pre-existed human values inherited from traditional society [2]. African socialists were convinced that the economic and social development cannot be promoted without the right socialization of productive and distributive processes. African leaders who believed these principles engaged themselves to restore righteousness in the society. African socialism shares with Marxism the same spirit which is the establishment of justice and freedom in society. The traditional society in Africa was not a society of class. Africa, before colonization was living what Marx and Engels were looking for. That is the proof that before the coming of western society imperialists, Africa was living in a far advance model of society [3].

In His book Essays on socialism Nyerere gave the real picture of socialism: "The true socialist may not exploit its fellows. So that if the members of any group within our society are going to argue that, because they happen to be contributing more to the national income than some other groups, they must therefore take for themselves a greater share of the profits of their own industry than they actually need; and if they insist on this in spite of the fact that it would mean reducing their group's contribution to the general income and thus slowing down the rate at which the whole community can benefit, then that group is exploiting (or trying to exploit) its fellow human being. It is displaying a capitalist attitude of mind." [1]. It means that any attitude of exploitation of one's fellow human may be against the principles and ethics of socialism. So the spirit of socialism is against exploitation. That is one of the reasons of the battle of Marx. In his book the communist manifesto we read: "The distinguishing feature of communism is not the abolition of property generally, but the abolition of bourgeois property. But modern bourgeois private property is the final and most complete expression of the system of producing and appropriating product, that is based on class antagonisms, on the exploitation of the many by the few." [3]

That's why when bourgeois society is destroyed, national differences and antagonisms between people are daily more and more vanishing. Then the exploitation of one individual by another is put an end as well the exploitation of one nation by another. This level is the proof of the political supremacy of the proletariat. According to Marx and Engels, the abolition of classes will allow the reorganization of the structure of the society. Then instead of a majority working for the minority, the entire society will then be part of production. The communism is focused on honest production and equable distribution [3].

The same way, Nyerere wrote: "For when a society is so organized that it cares about its individuals, then, provided he is willing to work, no individual within that society should worry about what will happen to him tomorrow... This is exactly what traditional African succeeded in doing" It means that the work was a valuable duty for each individual in traditional African society. Through the concept of African socialism, according to Nyerere emphasis should be on sensi-

${ }^{1}$ Nyerere, Ujamaa, The basis of African socialism, p. 3. 
tizing people to be involved in production. That's why he continued and say that if you received a visitor treat him as visitor during two days, after that take him to the farm. He was convinced that in a really socialist Country, no person exploits another; everyone who is physically able to work does so [4]. According to Nyerere, without an acceptance of human equality there can be no socialism. He insisted on the principle of human equality as principle of socialism in many dimensions such as social, economic and political organization.

\section{The Collapse of African Socialism}

The collapse of African socialism has diverse reasons. In this research we shall be focused on the following: problem of consistency, Misunderstanding of the concept, Lack of trust in the vision, Lack of security strategy.

\subsection{Problem of Reconciliation (Direct Consequence of Colonialism)}

In his book entitled "Class struggle in Africa" Nkrumah raised an importance issue which is the diverse differences between African Countries in politics and socio-economic patterns. When some were still in a deep traditional conservatism, some others were in a high industrialization and others were in between modernism and traditional. This reality made the task of synchronization between Countries difficult. Different Countries, different realities, and different interest. The first difficulty was regional reconciliation. The other problem, national reconciliation, was even worst. Colonialism has created two major classes: privileged classes and oppressed classes [5]. The first one was in the mercy of imperialists and the second one was abused. It was difficult to build trust between these two classes. As the main idea of African socialism was the restoration of justice and equality, it could not succeed. The imperialists created social classes in the sake of neo-colonialism. It would be difficult to merge privileged and oppressed classes into the same political ideology. Nkrumah also mentioned the input of education in the creation of social classes in Africa, especially those who went abroad to study. Most of them become alienated from tribal and village roots. According to Nkrumah their aims are political power, social positions, and professional status. Even after building excellent schools and training centers, Africans still prefer to go abroad for studies. From that perspective Nkrumah noticed that their purpose is not radical transformation or society or the establishment of a true African socialism, but to replace the colonial power [5].

\subsection{Misunderstanding of the Concept}

Some African political leaders and thinkers used the concept "socialism" accordingly, when they described it as a complex of social purposes such as economic policies, organizational patterns, state structure, and ideologies which can lead African nations to their destiny. For such leaders, the purpose to unit African society in the socialist direction has benefits such as harmonize the humanism of 
traditional African life with modern society perspectives. Many citizens misunderstood the concept and the application of socialism. That's why the more relevant ideologist of socialism, like Kwame Nkrumah and Modibo Keita were dethroned by militaries. Ghanaians were tired of Nkrumah and his rhetoric. In 1966 when he was dethroned in a military coup, there was much joy and jubilation in the streets of Ghana. Many Malians clap and dance as well when Modibo Keita was arrested, because they misunderstood his politics. The socialism was for the citizens, but unfortunately they couldn't understand. That one can be explained by the consequence of ignorance of the majority. Also many citizens were not ready for sacrifice. Socialism as Nyerere mentioned does not appear it has to be built. So one can say that the Citizens were more focused on today than tomorrow. It's always difficult to win a battle you are fighting on the behalf of somebody who sees you as an enemy. The contrast was so obvious, because the educated people were running after positions, the ignorant ones were confused and the socialists' idealists were under multiple pressures such as pressure from assimilated intellectuals, pressures from colonialists and pressure from the citizens they were fighting for.

\subsection{Lack of Agreement in the Vision}

The other leaders, such as Nyerere, Nkrumah, Sekou Toure, Modibo Keita trusted in the success of socialism. They even suggested that African should exploit their cultures and value to build a system which is completely different from capitalism. A new system conceived by Africans and applied in Africa for the sake of citizens. African socialism claimed that it was neither the opposite of capitalism, nor a response to it, but something completely different.

Leopold S. Senghor, although favoring some kind of return to African communalism but insisted on the fact that the refashioned African society must accommodate the "positive contribution" of colonial rule, "such as the economic and technical infrastructure and the French educational system". The economic and technical infrastructure of even French colonialism and the French educational system must be assumed, though this can be shown to be imbued with a particular socio-political philosophy. Senghor has, indeed, given an account of the nature of the return to Africa. His account is highlighted by statements using some of his own words: that the African is "a field of pure sensation"; that he does not measure or observe, but "lives" a situation; and that this way of acquiring "knowledge" by confrontation and intuition is "negro-African"; the acquisition of knowledge by reason, "Hellenic".

\subsection{Lack of Security Strategy}

One of the biggest mistakes of African socialism was the absence of military strategy [6].

With the time the old master came into the "dance" in order to destroyed African vision about complete independence [7]. It was difficult for each country 
to provide genuine protection in national level. So finally, Countries started to go back to the imperialist strategy to survive [8]. No Country cannot claim the desire to prosper without building a strong military strategy.

In his book Class Struggle in Africa, Nkrumah gave some quality explanation to that fact. He wrote: "The majority of Africa's Armed forces and police came into existence as part of the colonial coercive apparatus. Few of their members joined national liberation struggles. For the most part, they were employed to perform police operation against it." [5]. Nkrumah recognized that some of the officers were supporting socialist revolutionary ideology, but most of the officers were succumbed to the same bourgeois indoctrination as their older fellow officers. It's unfortunate to see that militaries were not supportive in majority to the socialist ideology. That can explain the reason of multiple military coup d'état in Africa. Instead of being under the socialist revolutionary party, in many cases armies were a danger for the civilian leaders. Because the training of militaries was not based on understanding but blind obedience. The proof is that from January 1963 to December 1969, 25 coup d'état have taken place in Africa. The observation of Nkrumah is still relevant now in our days, due to the fact that the structure of the Army and the police does not give confidence to the citizens. In most African countries we do have army of repression not a defensive army. It's difficult for our armies to stand before the enemy to protect the interest of the nation [9].

\section{What Lesson to Learn about African Politics?}

Even though Africans have great and famous scientists in diverse areas, still there is problem to maintain peace and unity. African politics suffers from many issues such as personal interest, lack of patriotism. From the beginning of independence up now the same problems have been facing everywhere in Africa. It's not possible to build socialism upon individualism ideology. The way African want to build socialism is funny and dramatic. The funny thing is when people are claiming to be socialists and individualists at the same moment. It appears like drama in the sense that the one who is claiming to be socialist, knows for the sure that he is not one. How come ones can desire something and its opposite at the same moment? It's like setting the air condition on and keeps complaining of the weather. From above study we can see clearly that the first enemy of Africa is Africans themselves. One may wonder, what to do?

\subsection{Ideological Training Based on Nationalism}

Nationalism or Patriotism ideology means being faithful to ones' nation or country. It is the willingness to be devoted, to accept self-sacrifice for the interests of the country. Socialism cannot function without patriotism. The dictatorial regime force people to serve the nation and defend its interests. But in socialism citizens are trained to serve the nation with love and devotion. The dedication of the people can readily eliminate fraud, corruption and unfaithfulness. A 
patriot sees the state first and then himself after. The culture of patriotism is not a new value in African society; it's just a value distorted. When people are proud of their nation and have examples to follow, so officials don't need any extra effort to win the trust of citizens. About patriotism, the first example must be shown by officials and then the others follow. China is a perfect example in that case. Chinese people are proud of their nation and their leaders [10].

Rebellions and civilian wars in Africa can be explained by the lack of patriotism. In many cases Rebels and loyalist governments are all mercenaries, they use citizen to satisfy their personal target. They all serve the population as a shield to get what they really want. The future belongs to those States that have managed to bring their people to act as good patriots. Freedom in this case is not measured by the impunity, rather to serve with genuine love without external constraint [11].

\subsection{Put Emphasis on Education}

One of the mega issues in African politics is education systems and programs. Most of time, the contents of schooling program are inspired from western pattern. But western society and African society are two completely different realities. Understanding that Africa is historically and culturally rich, shall be one of the targets to be fulfilled. The key question in that fact is: which kind of citizen is needed for Africa? The success criteria must be defined according to the need and work accordingly. It's so easier for an African citizen even leader to sacrifice his own nation with the promise of exile. It's true that during colonization African were forced to be taken out of the continent. But now nobody is forcing, but the move is still going on. Africa needs powerful ideological teaching about human value, nationalism, the importance of hard work. In that case, China may be a right source of inspiration [12].

In China, under Mao, a discipline, educated, united and hard worker citizen was needed, that's why Mao was able to succeed. But you can never succeed to establish unity when there is controversial issue among people. Knowing that, Mao could say: "The only way to settle questions of an ideological nature or controversial issues among the people is by the democratic method, the method of discussion, of criticism, of persuasion and education, and not by the method of coercion or repression. To be able to carry on their production and studies effectively and to arrange their lives properly, the people want their government and those in charge of production and of cultural and educational organizations to issue appropriate orders of an obligatory nature. It is common sense that the maintenance of public order would be impossible without such administrative regulations. Administrative orders and the method of persuasion and education complement each other in resolving contradictions among the people. Even administrative regulations for the maintenance of public order must be accompanied by persuasion and education, because in many cases regulations alone will not work" [13]. 
Without proper program of education, the condition of Africa will remain the same. Until people receive quality education there is no hope for freedom. The lasting freedom is understanding of social values and ones' role in the preservation of those values. It shall start by oneself and reach to others. That is the need to have a sound and profound knowledge if there is no self-knowledge. In many cases, African are good in foreign languages but fair good in local language. The center of education shall be valuable knowledge. In Mali there is a saying: "It's good to know how to ride a horse, even to climb three, but the best knowledge is self-knowledge"2. Violence and hatred among ethnical groups and religion believes in Africa are source of ignorance of social value. We are convinced that all these realities are changeable if citizen received social and ideological training basically in schools and generally to the entire society.

\subsection{Set a New Vision to Establish a New Trend}

A man without vision is likely going to fulfill somebody else's vision unconsciously. Likewise a people without vision is ready to be exploit by another. When young people think about their destiny, they will fight the right battle for it. The very need is to help the new generation that there is hope in Africa, and that there are that hope. Then African leaders should train the young people and trust them to do better. The new socialism should be the global vision about the development of Africa in the whole continent. African should stop importing things that they can produce locally. In his book entitled new colonialism, Nkrumah wrote: "African States are importing large amounts of food than ever before from abroad. This trend must be stopped by a carefully planned expansion of our own agriculture" [14]. The new generation should be trained to love local production than local farmers will be encouraged to produce more. At the same time trade and agriculture will grow up. Time has come for African to open eyes and see far for the sake of the destiny of Africa.

Another aspect is to refuse African land to the unnecessary battle place. When you look at the different rebellion groups in Africa, they are trained and equipped by other people to fight their own country mate. The war in Africa is no more border issues but inside matters. Until citizens develop ideological interest for their own nation, rebellion will continue.

\section{Conclusion}

Firstly, the African socialism failed mainly because of African leaders. Secondly, communal co-existence suggested by African socialism for the present African socialism is not plausible in an over populated geographical area as the African states, except if sanctions will be applied in proportions to the populations. However, that could be a drift towards capitalism. Communalism is not peculiar to Africa. It is found in traditional industrial societies all over the world. Thirdly, African socialists assert that the bond of brotherhood and unity, in the tradition-

${ }^{2}$ Meaning, self-knowledge is the highest. 
al society of Africa was very strong; they therefore suggest that these brotherhood and unity should be encouraged in the modern society. This is really a good suggestion; but then if the bond of brotherhood and unity was that strong, why did Africans sell their fellow African brothers into slavery in exchange for the goods of the white man? [15]

\section{References}

[1] Nyerere, J.K. (1969) Nyerere on Socialism. Oxford University Press, Dar es Salaam, $58 \mathrm{p}$.

[2] Nkrumah, K. (1965) Consciencism; Philosophy and Ideology for Decolonization and Development with Particular Reference to the African Revolution. Monthly Review Press, New York, 122 p.

[3] Marx, K. and Engels, F. (1948) The Communist Manifesto. Centennial Ed., New York Labor News Co., New York, 75 p.

[4] Nyerere, J.K. and Tanzania. (1968) Freedom and Socialism. Uhuru na ujamaa; a Selection from Writings and Speeches, 1965-1967. Oxford University Press, Dar Es Salaam, New York, 422 p.

[5] Nkrumah, K. (1970) Class Struggle in Africa. Panaf Books Ltd., London, 96 p.

[6] Committee on Foreign Relations, Subcommittee on African Affairs, May 1992, 36 p.

[7] United Nations. Office for Disarmament Affairs. (1992) Disarmament and Security in Africa. Disarmament Topical Papers, United Nations, New York, 150 p.

[8] Solomon, H. and Van Aardt, M. (1998) Caring Security in Africa: Theoretical and Practical Considerations of New Security Thinking. ISS Monograph Series, Institute for Security Studies, Halfway House, South Africa, 125 p.

[9] Celso, A. and Nalbandov, R. (2016) The Crisis of the African State: Globalization, Tribalism, and Jihadism in the Twenty-First Century. 238 p.

[10] Gustafsson, K. and Lunds universitet. Centrum för öst-och sydöstasienstudier. (2014) Is Patriotism Distinct from Nationalism?: The Meaning of patriotism in China in the 2000s. Working Papers in Contemporary Asian Studies., Centre for East and South-East Asian Studies, Lund University, Sweden, 25 p.

[11] Falola, T. and Essien, K. (2014) Pan-Africanism, and the Politics of African Citizenship and Identity. Routledge African Studies, Routledge, New York, 254 p.

[12] Bates, R.H., Mudimbe, V.Y. and O’Barr, J.F. (1993) Africa and the Disciplines: The Contributions of Research in Africa to the Social Sciences and Humanities. University of Chicago Press, Chicago, 245 p.

[13] Mao, Z. (1967) On Practice. On Contradiction. On the Correct Handling of Contradictions among the People. National Book Agency, Calcutta, 161 p.

[14] Nkrumah, K. (1966) Neo-Colonialism; the Last Stage of Imperialism. International Publishers, New York, 280 p.

[15] Hine, D.C., Hine, W.C. and Harrold, S. (2006) The African-American Odyssey: Combined Volume. 3rd Edition, Pearson Prentice Hall, New Jersey, 3 p. 